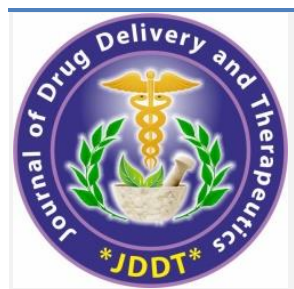

Access Full Text Article
Available online on 15.11.2021 at http://jddtonline.info

\section{Journal of Drug Delivery and Therapeutics}

Open Access to Pharmaceutical and Medical Research

Copyright (C) 2021 The Author(s): This is an open-access article distributed under the terms of the CC BY-NC 4.0 which permits unrestricted use, distribution, and reproduction in any medium for non-commercial use provided the original author and source are credited

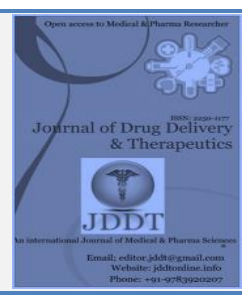

Research Article

\title{
Cross-sectional Survey on Online Learning during COVID-19 Pandemic in Bangladesh
}

\author{
Devaroti Bhattacherjee ${ }^{1}$, Sajidur Rahman Akash ${ }^{1}$, Sanjida Islam Saiky', Nur E Naznin Chaity ${ }^{1}$, MD. Ariful \\ Islam $^{1}$, Nusrat Jahan ${ }^{2}$, Imtiaj Hossain Chowdhury2*
}

1 Department of Pharmacy, Bangladesh University, Dhaka-1207, Bangladesh.

2 Department of Pharmacy, Jahangirnagar University, Savar, Dhaka-1342, Bangladesh.

Article Info:

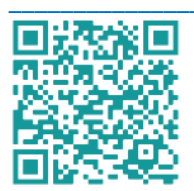

Article History:

Received 28 September 2021

Reviewed 30 October 2021

Accepted 07 November 2021

Published 15 November 2021

Cite this article as:

Bhattacherjee D, Akash SR, Saiky SI, Chaity NEN, Islam MA, Jahan N, Chowdhury IH, Cross-sectional Survey on Online Learning during COVID-19 Pandemic in Bangladesh., Journal of Drug Delivery and Therapeutics. 2021; 11(6):135-142

DOI: http://dx.doi.org/10.22270/jddt.v11i6.5083

*Address for Correspondence:

Corresponding author: Imtiaj Hossain Chowdhury, Department of Pharmacy, Jahangirnagar University, Savar, Dhaka-1342, Bangladesh. Email:

,imtiaj.eham@gmail.com

\begin{abstract}
The educational system across the world had drastically been affected due to the pandemic outbreak of COVID-19. In this circumstance, Teaching and learning shifted from traditional way which involves face-to-face interaction among teachers and students physically in a classroom, to online learning either synchronously or asynchronously. Therefore, the aim of this study is to monitor the level of students' perception towards online learning during the ongoing COVID-19 pandemic situation. The study adopted the way of quantitative approach by conducting a survey which was collected via a standardized online questionnaire. Data collected from 699 respondents were analyzed using SPSS 23 software. In spite of having been failed to get theoretical and practical experience as well as expected results, majority of the respondents had positive perceptions towards online learning and accepted this as the new method of learning with online application tools. The outcomes of the study will facilitate educational institutions and policy makers to take this online learning process to the next level in a prospective way.
\end{abstract}

Keywords: Online Learning, COVID-19, Pandemic, Bangladesh.

\section{INTRODUCTION:}

The world is going through the most critical and troublesome times in its history due to the widespread transmission of COVID-19 pandemic among population of different countries throughout the world [1]. Severe acute respiratory distress syndrome-coronavirus-2 (SARS-CoV-2) was responsible to cause COVID-19, was primarily elicited in China in December, 2019, and announced as a pandemic disease by the World Health Organization (WHO) on March 11,2020 [2]. Initially, it was prescribed as pneumonia with unknown etiology, however, after several studies, Chinese Disease Control and Prevention (China CDC) was declared the cause on January 8, 2020 [3]. The coronavirus genome is very susceptible to mutations which cause genetic drift and escape from immunological recognition. B-cell and T-cell epitopes anticipated from the SARS coronavirus have been reported as the disease has spread to become a pandemic. Numerous variants have been discovered that could produce drifts by combining epitope information with viral variants. Among these variants, $23403 \mathrm{~A}>\mathrm{G}$ variant (p.D614G) in spike protein B-cell epitope is common in European countries, including the Netherlands, Switzerland, and France, but rare in China. [4]. There are 5775 different genomic variants, ISSN: 2250-1177 with 2969 missense mutations, 1965 synonymous mutations, 484 mutations within the non-coding regions, 142 non-coding deletions, 100 in-frame deletions, 66 noncoding insertions, 36 stop-gained variants, 11 frameshift deletions and two in-frame insertions. The PRC (People's Republic of China) Centre for Disease Control (CDC) discovered that this unusual pneumonia was caused by a novel coronavirus called Novel Coronavirus Pneumonia (NCP) after examining respiratory samples [5]. The International Committee on Virus Taxonomy (ICTV) called the virus Severe Acute Respiratory Syndrome Coronavirus-2 (SARS-Cov-2) within a few days [6]. In February 11, 2020, the World Health Organization (WHO) designated this pneumonia as Coronavirus disease-19 (COVID-19). [7].

The coronavirus disease (COVID-19) pandemic has caused an unprecedented crisis in all areas. In the field of education which has been hit hard, the situation has resulted in the widespread shutdown of face-to-face operations of educational institutions in over 190 countries in order to limit the virus's spread and lessen its impact. According to data from the United Nations Educational, Scientific and Cultural Organization (UNESCO), more than 1.2 billion students at all levels of education worldwide had stopped 
having face-to-face lessons by mid-May 2020 [8]. Due to the widespread of Coronavirus disease (COVID-19) in China, most Chinese universities have begun to offer online education in order to meet the government's "nonstop teaching and learning" criteria. In a short time period, millions of faculty members began to lecture in front of a computer screen, and their students were advised to stay at home and take the courses via the internet. Besides China, with the spread of COVID-19 across the world, 61 nations in Africa, Asia, Europe, the Middle East, North America, and South America have declared or implemented school and university closures, with the majority of universities enforcing localized closures as of March 13. (UNESCO, 2020) [9]. Almost all the countries are maintaining their educational operations online in the pandemic situation [10]. The majority of global institutions use both synchronous and asynchronous online teaching methods: synchronous refers to faculty and students meeting at a predetermined time for interactive learning classes, whereas asynchronous refers to the faculty delivering the course without interaction with the students [9]. Some students without reliable internet access and/or technology find it difficult to engage in digital learning; this gap exists across countries and between income brackets within countries. According to OECD data, while 95 percent of students in Switzerland, Norway, and Austria have access to a computer for schooling, only 34\% of students in Indonesia have. [11]. The C-19 issue, on the other hand, has accelerated the push for online education, and Bangladesh, like other developing nations, is seeking to adapt to it in both public and private educational institutions [12]. The Government of Bangladesh had to shut down all educational and learning institutions on March 17, 2020, after confirming the first COVID-19 patient on March 8, 2020, to limit the rapid spread of the noxious virus, according to The Business Standard June 2020. [13] About 40 million students are served by Bangladesh's educational system. Both formal and non-formal learning opportunities are available [14]. Bangladesh is one of the countries most affected by a complete closure, with nearly 40 million youngsters enrolled in school.[15]. In the center of the country's administration, teachers have just recently begun to use a combination of real-time interactive courses and classes, as well as pre-recorded materials and homework-based digital sessions on a small scale [16]. Educational institutions pursued a sort of digitization by adopting a variety of online platforms, such as Zoom, Moodle, Google Classroom, WhatsApp, and others [17]. Nonetheless, educational institutions use a variety of teaching-learning mediums, such as television, radio, and social media platforms, to reach students from various backgrounds. However, according to the household income and expenditure survey 2020, approximately 12.70 percent of poor families do not own a mobile phone, despite the fact that students require at least a Smartphone and a stable internet connection to participate in online education [13]. Bangladesh has already been linked to various issues and challenges in the field of digitalization, including online learning, digital infrastructure, and digital inefficiency, all of which are related to the phrase digital divide [18]. Students may experience unique challenges relating to online class preparedness, participation, and activities after transferring to online classrooms during the pandemic [13]. Furthermore, psychological anguish is increased when there is a lack of security and no physical presence while learning. [19]. According to the Daily Campus in June 2020, a student and his mother attempted suicide due to the student's unwillingness to take the online exam [20].

Online learning is defined as "learning experiences in synchronous or asynchronous environments using various devices (e.g., mobile phones, laptops, etc.) with internet connection. Students can learn and communicate with instructors and other students from anywhere (independent) in these contexts" [21]. Remote learning, comfort, and accessibility were among the benefits, while inefficiency and trouble preserving academic integrity were among the drawbacks. Faculty should be trained in using online modalities and devising lesson plans with less cognitive load and more interactivity, according to the guidelines [22]. Online education has the ability to reach a larger audience, thereby leveling the playing field for students who are traditionally underserved in terms of educational opportunities [23]. Students in online education generally have diverse backgrounds in terms of gender, age, academic subject, and prior education, which influences not just their preference for an online course style but also their academic success in general [24].A similar theory was advocated, claiming that students' attitudes toward educational technology had a direct impact on their learning process, and that a negative attitude had a detrimental impact on their academic performance [25]. The so-called lockdown, coronavirus measures, and social separation did not work in a densely populated country with a population of 165 million people [13]. As a result, Bangladesh is currently experiencing widespread population expansion, as common citizens are not sufficiently informed of their health to prevent the coronavirus from spreading [26]. According to a recent survey, while $40 \%$ of students take online classes, over $50 \%$ of students are unable to do so due to a lack of device availability. However, the majority of them (70\%) are graduates of private universities. Students often believe that the practicality and efficacy of online courses are questionable. [13]. Nonetheless, educational institutions use a variety of teaching-learning mediums, such as television, radio, and social media platforms to reach students from various backgrounds. However, according to the household income and expenditure survey 2020, approximately 12.70 percent of poor families do not own a mobile phone, despite the fact that students require at least a Smartphone and a stable internet connection to participate in online education [13].

As such, the pandemic has accommodated students and teachers to induce together in a classroom. In this circumstance, A few questions have emerged: which online platform is more feasible to utilize by mass number of students; which model of class (synchronous or asynchronous model) is more effective and successful to follow; what is the best duration for online lectures; what are students and teachers' appreciations of the online learning process? To answer these questions, we have performed a cross-sectional study across the country between February'21 and August'21.

\section{METHODS}

It was a cross-sectional survey which was conducted from February'21 and August'21. A structured online survey questionnaire was used to collect data by using social media across Bangladesh. The purposive sampling technique was used to select the participants. Google Forms containing the study questionnaire was distributed to different students' group of social media. In order to ensure their participation, a formal text was sent to them through face book messenger and what's app. A friendly reminder was sent to potential respondents to ensure the highest possible response rate. Completed questionnaires were collected in a structured way to ensure confidentiality and to prevent any response bias. Participants were aware of the study aim or outcomes to reduce the risk of any possible bias. The questionnaire was self-administered without intervention by the authors 
or any specific person, and it did not contain any identifying data of the participants to ensure confidentiality. Questionnaires with incomplete information or missing data were excluded from the analysis. The inclusion criterion was: respondents those who have participated online learning in COVID-19 PANDEMIC situation. Exclusion criteria were: respondents those who were illiterate, not willing to participate, not psychologically fit to understand the questions and haven't participated online learning in COVID-19 pandemic situation.

\section{RESULTS}

Among 699 study respondents, $43.5 \%$ were male and $56.5 \%$ were female. Among them majority of the male respondents were residing in urban areas (64.1\%) than rural areas (35.9\%). Similarly Female respondents were residing in urban areas $(71.9 \%)$ than rural areas $(28.1 \%)$

Table 1: Distribution of study respondents by Gender and their Area of residence

\begin{tabular}{|l|l|l|c|}
\hline \multicolumn{2}{|c|}{ Gender of respondents } & \multicolumn{2}{c|}{ Area of residence of the respondents } \\
\hline Variables & Frequency of the respondents & Rural & $195(64.1 \%)$ \\
\hline Male & $304(43.5)$ & $109(35.9 \%)$ & $284(71.9 \%)$ \\
\hline Female & $395(56.5)$ & $111(28.1 \%)$ & \\
\hline
\end{tabular}

In this study, majority of the respondents $(58.2 \%, \mathrm{n}=407)$ were in age range 20-23 years and lowest number of respondents $(2.6 \%, \mathrm{n}=18)$ were in $28-31$ years range. The mean age was $2.77 \pm 0.928$. In this case, data are fairly symmetrical as the value of skewness $(-0.38)$ is in range of 0.5 to 0.5 . Majority of the respondents $(84 \%, n=587)$ were muslim by religion and positive value of skewness (1.857) indicates data are skewed/peaked right. Majority of the respondents $(47.2 \%, \mathrm{n}=330)$ family members size was $2-4$ persons, followed by 5-7 persons $(38.1 \%, n=266)$ and less respondents $(1 \%, \mathrm{n}=7)$ family size was above 10 persons. The mean family size was $1.69 \pm 0.742$. As the value of skewness (0.727). About $36.9 \%$ of the respondents( $n=256)$ had family monthly income between 30001 to 60000 taka and mean income was $1.97 \pm 0.92$. Majority of the respondents $(49.2 \%, \mathrm{n}=344)$ were enrolling Undergraduate (Honor's)/ MBBS/Diploma degree followed by HSC/Alim/Vocational educational level $(26 \%, n=182)$. The mean level of education was $3.19 \pm 1.128$ and skewed left.

Table 2: Demographic information of study respondents.

\begin{tabular}{|c|c|c|c|c|c|c|c|c|}
\hline Sl & Variables & Total & Male & Female & Mean & $\begin{array}{l}\text { Std. } \\
\text { Deviation }\end{array}$ & Skewness & $\begin{array}{l}\mathbf{P} \\
\text { Value }\end{array}$ \\
\hline \multicolumn{9}{|c|}{ Socio-demographic variables of respondents } \\
\hline \multirow[t]{6}{*}{1} & Age of Respondents & & & & & & & .000 \\
\hline & $12-15$ & $98(14 \%)$ & $9(3 \%)$ & $89(22.5 \%)$ & \multirow{5}{*}{2.77} & \multirow{5}{*}{0.928} & \multirow{5}{*}{-0.380} & \\
\hline & $16-19$ & $90(12.9 \%)$ & $42(13.8 \%)$ & $48(12.2 \%)$ & & & & \\
\hline & $20-23$ & 407 (58.2\%) & $196(64.5 \%)$ & $211(53.4 \%)$ & & & & \\
\hline & $24-27$ & $86(12.3 \%)$ & $49(16.1 \%)$ & $37(9.4 \%)$ & & & & \\
\hline & $28-31$ & $18(2.6 \%)$ & $8(2.6 \%)$ & $10(2.5 \%)$ & & & & \\
\hline \multirow[t]{3}{*}{2} & \multicolumn{7}{|c|}{ Religion of Respondents } & 0.019 \\
\hline & Muslim & $587(84 \%)$ & $244(80.3 \%)$ & $343(86.8 \%)$ & \multirow[b]{2}{*}{1.16} & \multirow[b]{2}{*}{0.367} & \multirow[b]{2}{*}{1.857} & \\
\hline & Non-muslim & $112(16 \%)$ & $60(19.7 \%)$ & $52(13.2 \%)$ & & & & \\
\hline \multirow[t]{5}{*}{3} & \multicolumn{7}{|l|}{ Family Members Size } & 0.274 \\
\hline & 2-4 persons & $33047.2 \%)$ & $137(45.1 \%)$ & $193(48.9 \%)$ & \multirow{4}{*}{1.69} & \multirow{4}{*}{0.742} & \multirow{4}{*}{0.727} & \\
\hline & 5-7 persons & $266(38.1 \%)$ & $123(40.5 \%)$ & $143(36.2 \%)$ & & & & \\
\hline & 8-10 persons & $96(13.7 \%)$ & $39(12.8 \%)$ & $57(14.4 \%)$ & & & & \\
\hline & $>10$ persons & $7(1 \%)$ & $5(1.6 \%)$ & $2(0.5 \%)$ & & & & \\
\hline \multirow[t]{5}{*}{4} & Family Monthly Ince & & & & & & & .000 \\
\hline & 0 to $30000 \mathrm{tk}$ & $256(36.6 \%)$ & $132(43.4 \%)$ & $124(31.4 \%)$ & \multirow{4}{*}{1.97} & \multirow{4}{*}{0.920} & \multirow{4}{*}{0.614} & \\
\hline & 30001 to $60000 \mathrm{tk}$ & $258(36.9 \%)$ & $108(35.5 \%)$ & $150(38 \%)$ & & & & \\
\hline & 60001 to $90000 \mathrm{tk}$ & $135(19.3 \%)$ & $54(17.8 \%)$ & $81(20.5 \%)$ & & & & \\
\hline & $>900000 \mathrm{tk}$ & $50(7.2 \%)$ & $10(3.3 \%)$ & $40(10.1 \%)$ & & & & \\
\hline
\end{tabular}


\begin{tabular}{|l|l}
5 & Level of Education
\end{tabular}

\begin{tabular}{|l|l|l|l|}
\hline & & & .000 \\
3.19 & 1.128 & -0.890 & \\
& & & \\
& & & \\
& & & \\
\hline
\end{tabular}

In table $3 \& 4$, Percent of responses and percent of cases are displayed. Percent of response is the percentage of each response out of total responses from the given data-set. Thus, the sum total of percent of response is 100 . From table 3, 699 respondents had provided 954 opinions regarding learning apps which were used during online classes. Of 699 respondents, $56.3 \%, 32.9 \%$ and $8.5 \%$ had used Zoom app (76.8\% of the respondents), Google Meet (44.9\% of the respondents), Microsoft teams (11.6\% of the respondents) respectively. Only $2.3 \%$ had used others $(3.1 \%$ of the respondents). Table 4 illustrates respondents $(n=699)$ preferences on operating device/technology and suitable mobile operator for pursuing online classes. About 902 and 812 opinions had found regarding Operating device/technology and suitable mobile operator in online classes respectively. Majority of the respondents $(64.9 \%$, $\mathrm{n}=585$ ) had habituated with mobile phone as operating device $(83.7 \%$ of the respondents) to pursue their online classes. About 44.7\% ( $\mathrm{n}=363)$ stated that they had used Grameenphone mobile operator (65.4\% of the respondents) in online classes followed by Robi mobile operator $31.0 \%$ of the respondents), Banglalink mobile operator $(25.0 \%$ of the respondents) and Teletalk mobile operator $(24.9 \%$ of the respondents)

Table 3: Response from study respondents regarding learning apps that are used during online classes (Multiple response)

\begin{tabular}{|c|c|c|c|c|}
\hline & & \multicolumn{2}{|c|}{ Responses } & \multirow[b]{2}{*}{ Percent of Cases } \\
\hline & & $\mathbf{n}$ & Percent & \\
\hline \multirow[t]{4}{*}{ Learning apps during online classes ${ }^{\mathrm{a}}$} & Zoom & 537 & $56.3 \%$ & $76.8 \%$ \\
\hline & Google Meet & 314 & $32.9 \%$ & $44.9 \%$ \\
\hline & Microsoft teams & 81 & $8.5 \%$ & $11.6 \%$ \\
\hline & Others & 22 & $2.3 \%$ & $3.1 \%$ \\
\hline \multicolumn{2}{|l|}{ Total } & 954 & $100.0 \%$ & $136.5 \%$ \\
\hline
\end{tabular}

Table 4: Response from study respondents regarding Operating device/technology and suitable mobile operator used in online classes (Multiple response).

\begin{tabular}{|c|c|c|c|c|c|c|c|c|c|}
\hline & \multicolumn{2}{|c|}{ Responses } & \multirow[b]{2}{*}{$\begin{array}{l}\text { Percent } \\
\text { of Cases }\end{array}$} & & & \multicolumn{2}{|c|}{ Responses } & \multirow{2}{*}{$\begin{array}{l}\text { Percent of } \\
\text { Cases }\end{array}$} \\
\hline & & n & Percent & & & & $\mathrm{n}$ & Percent & \\
\hline \multirow{4}{*}{$\begin{array}{l}\text { Operating } \\
\text { device/technology in } \\
\text { online classes }^{\mathrm{a}}\end{array}$} & Mobile Phone & 585 & $64.9 \%$ & $83.7 \%$ & \multirow{5}{*}{$\begin{array}{l}\text { Mobile } \\
\text { operator used } \\
\text { in online } \\
\text { classes }^{\mathrm{a}}\end{array}$} & $\begin{array}{l}\text { Grameen- } \\
\text { Phone }\end{array}$ & 363 & $44.7 \%$ & $65.4 \%$ \\
\hline & Laptop/Desktop & 237 & $26.3 \%$ & $33.9 \%$ & & Banglalink & 139 & $17.1 \%$ & $25.0 \%$ \\
\hline & Tablet & 72 & $8.0 \%$ & $10.3 \%$ & & Robi & 172 & $21.2 \%$ & $31.0 \%$ \\
\hline & Others & 8 & $0.9 \%$ & $1.1 \%$ & & Teletalk & 138 & $17.0 \%$ & $24.9 \%$ \\
\hline \multicolumn{2}{|l|}{ Total } & 902 & $100.0 \%$ & $129.0 \%$ & & & 812 & $100.0 \%$ & $146.3 \%$ \\
\hline
\end{tabular}

Table 5 represents attitude and practice related dichotomous response of the students regarding online classes. Out of 09 statements, respondents showed positive response in 06 statements where they stated that had suitable place at home, high speed internet at home, participated in online examinations, no interruption during examinations, posed mental pressure and personal or familial pressure. In contrast, 03 negative experiences had 
displayed from respondents which were they failed to enjoy online classes, missed theoretical and practical experience from online classes, and didn't get expected results through online classes. Overall mean score obtained from this data was ranked low that concluded that the students were not accurately compatible with online classes.

Table 5: Distribution of attitude and practice related dichotomous response of the students regarding online classes.

\begin{tabular}{|l|l|l|l|l|}
\hline Statements & Yes & No & Mean & Interpretation \\
\hline Is your home suitable for the online class? & $469(67.1 \%)$ & $230(32.9 \%)$ & 1.33 & Low \\
\hline Do you enjoy your online classes? & $317(45.4 \%)$ & $382(54.6 \%)$ & 1.55 & Low \\
\hline Do you have high speed internet at home? & $377(53.9 \%)$ & $322(46.1 \%)$ & 1.46 & Low \\
\hline $\begin{array}{l}\text { Do you think online classes are giving you } \\
\text { theoretical and practical experience? }\end{array}$ & $179(25.6 \%)$ & $520(74.4 \%)$ & 1.74 & Low \\
\hline $\begin{array}{l}\text { Have you participated in any online } \\
\text { examinations? }\end{array}$ & $585(83.7 \%)$ & $114(16.3 \%)$ & 1.16 & Low \\
\hline $\begin{array}{l}\text { Are you participating in the online } \\
\text { examinations without any interruption? }\end{array}$ & $441(63.1 \%)$ & $258(36.9 \%)$ & 1.37 & Low \\
\hline $\begin{array}{l}\text { Are you getting the expected results through } \\
\text { online classes? }\end{array}$ & $207(29.6 \%)$ & $492(70.4 \%)$ & 1.70 & Low \\
\hline $\begin{array}{l}\text { Do you feel mental pressure while attending } \\
\text { online classes? }\end{array}$ & $466(66.7 \%)$ & $233(33.3 \%)$ & 1.33 & Low \\
\hline $\begin{array}{l}\text { Do you have any personal or family pressure } \\
\text { in this pandemic situation? }\end{array}$ & $471(67.4 \%)$ & $228(32.6 \%)$ & 1.33 & Low \\
\hline
\end{tabular}

In Table-6, student's perception regarding online classes discussed that consists 03 statements. From the values obtained from mean values of each statement, overall mean score was categorized as intermediate. From this finding, it can be concluded that perception of respondent's was not satisfactory with online classes.

Table 6: Distribution of responses of the respondents in domain student's perception.

\begin{tabular}{|c|c|c|c|c|c|c|c|}
\hline Statements & $\begin{array}{l}\text { Strongly } \\
\text { Agree }\end{array}$ & Agree & Neutral & Disagree & $\begin{array}{l}\text { Strongly } \\
\text { Disagree }\end{array}$ & Mean & Interpretation \\
\hline $\begin{array}{l}\text { Online classes are suitable } \\
\text { for all students. }\end{array}$ & 41 & 312 & 16 & 205 & 125 & 3.09 & Intermediate \\
\hline $\begin{array}{l}\text { Satisfaction in attending } \\
\text { online classes. }\end{array}$ & 31 & 168 & 248 & 163 & 89 & 3.16 & Intermediate \\
\hline $\begin{array}{l}\text { Experience in participating } \\
\text { online examination. }\end{array}$ & 33 & 199 & 276 & 126 & 65 & 2.99 & Intermediate \\
\hline Overall & & & & & & 3.08 & Intermediate \\
\hline
\end{tabular}

Table \#7 revealed that there were 3-4 online classes per day in relation to the academic attainment of the respondents except post graduate respondents (1-2 online classes per day). Majority of the respondents of Class 8-Class 10, SSC/Dhakil/Technical, HSC/Alim/Vocational, Undergraduate/MBBS/Diploma had reported that they had spent 4-6 hours per day for online classes. In contrary Respondents of Post-Graduation had spent 1-3 hours per day for online classes. Majority of the respondents of Class 8Class 10 stated that they had required 7-10 GB $(\mathrm{n}=54,49.5 \%)$ monthly data followed by 3-6 GB \& 11-14 GB $(\mathrm{n}=20,18.3 \%)$. Highest number of respondents of SSC/Dhakil/Technical had used 7-10 GB ( $\mathrm{n}=20,48.8 \%)$ followed by 11-14 GB ( $n=11,26.8 \%)$. Majority of the respondents from HSC/Alim/Vocational and Undergraduate/MBBS/Diploma had required 11-14 GB $(\mathrm{n}=49,26.9 \%)$ and $3-6 \quad \mathrm{~GB}(\mathrm{n}=83,24.1 \%)$ respectively. Respondents of Post-Graduation had required 3-6 GB $(n=7,30.4 \%)$ monthly data followed by 15-18 GB $(n=6,26.1 \%)$. Statement from majority of the respondents of SSC/Dhakil/Technical, HSC/Alim/Vocational, Undergraduate/MBBS/Diploma and Post-Graduation elicited that they had to spend 300-500 tk monthly to get online access for online classes and respondents from Class 8-Class 10 had embezzled $900+$ tk monthly for online classes. 
Table 7: Frequency and distribution responses to the questions regarding online classes by academic attainment of the respondents.

\begin{tabular}{|c|c|c|c|c|c|}
\hline \multirow[t]{2}{*}{ Variables } & \multicolumn{5}{|c|}{ Academic attainment } \\
\hline & $\begin{array}{l}\text { Class 8- Class } \\
10\end{array}$ & SSC/Dhakil/Technical & HSC/Alim/Vocational & $\begin{array}{l}\text { Under-graduate/ } \\
\text { MBBS/Diploma }\end{array}$ & Post-Graduation \\
\hline \multicolumn{6}{|c|}{ Online classes per day } \\
\hline $1-2$ & $16(14.7 \%)$ & $7(17.1 \%)$ & $80(44 \%)$ & $161(46.8 \%)$ & $15(65.2 \%)$ \\
\hline $3-4$ & $79(72.5 \%)$ & $30(73.2 \%)$ & $101(55.5 \%)$ & $175(50.9 \%)$ & $6(26.1 \%)$ \\
\hline $5+$ & $14(12.8 \%)$ & $4(9.8 \%)$ & $1(0.5 \%)$ & $8(2.3 \%)$ & $2(8.7 \%)$ \\
\hline \multicolumn{6}{|c|}{ Time duration of online classes per day } \\
\hline 1-3 Hours & $26(23.9 \%)$ & $11(26.8 \%)$ & $61(33.5 \%)$ & $177(51.5 \%)$ & $12(52.2 \%)$ \\
\hline 4-6 Hours & $56(32.7 \%)$ & $21(51.2 \%)$ & $86(47.3 \%)$ & $139(40.4 \%)$ & $7(30.4 \%)$ \\
\hline 7-9 Hours & $24(22.0 \%)$ & $9(22.0 \%)$ & $35(19.2 \%)$ & $19(5.5 \%)$ & $2(8.7 \%)$ \\
\hline $\begin{array}{l}10+ \\
\text { Hours }\end{array}$ & $3(21.4 \%)$ & $0(0.0 \%)$ & $0(0.0 \%)$ & $9(2.6 \%)$ & $2(8.7 \%)$ \\
\hline \multicolumn{6}{|c|}{ Monthly Data for online classes } \\
\hline $3-6 \mathrm{~GB}$ & $20(18.3 \%)$ & $3(7.3 \%)$ & $44(24.2 \%)$ & $83(24.1 \%)$ & 7 (30.4\%) \\
\hline 7-10 GB & $54(49.5 \%)$ & $20(48.8 \%)$ & $36(19.8 \%)$ & $64(18.6 \%)$ & $2(8.7 \%)$ \\
\hline $11-14 \mathrm{~GB}$ & $20(18.3 \%)$ & $11(26.8 \%)$ & $49(26.9 \%)$ & $66(19.2 \%)$ & $4(17.4 \%)$ \\
\hline $15-18 \mathrm{~GB}$ & $9(8.3 \%)$ & $2(4.9 \%)$ & $27(14.8 \%)$ & $56(16.3 \%)$ & $6(26.1 \%)$ \\
\hline $19 \mathrm{~GB}+$ & $6(5.6 \%)$ & $5(12.2 \%)$ & $26(14.3 \%)$ & 75 (21.8\%) & $4(17.4 \%)$ \\
\hline \multicolumn{6}{|c|}{ Monthly Expenditure for online classes } \\
\hline $\begin{array}{l}\text { 100-300 } \\
\text { Taka }\end{array}$ & $12(11.0 \%)$ & $4(9.8 \%)$ & $19(10.4 \%)$ & $34(9.9 \%)$ & $3(13.0 \%)$ \\
\hline $\begin{array}{l}\text { 300-500 } \\
\text { Taka }\end{array}$ & $26(23.9 \%)$ & $15(36.6 \%)$ & $57(31.3 \%)$ & $101(29.4 \%)$ & $7(30.4 \%)$ \\
\hline $\begin{array}{l}\text { 500-700 } \\
\text { Taka }\end{array}$ & $26(23.9 \%)$ & $9(22.0 \%)$ & $53(29.1 \%)$ & $95(27.6 \%)$ & $6(26.1 \%)$ \\
\hline $\begin{array}{l}\text { 700-900 } \\
\text { Taka }\end{array}$ & $12(11.0 \%)$ & $8(19.5 \%)$ & 33 (18.1\%) & $48(14.0 \%)$ & $4(17.4 \%)$ \\
\hline $\begin{array}{l}900+ \\
\text { Taka }\end{array}$ & $33(30.3 \%)$ & $5(12.2 \%)$ & $20(11.0 \%)$ & $66(19.2 \%)$ & $3(13.0 \%)$ \\
\hline
\end{tabular}

As illustrated in table 8, with regards to the academic attainment of respondents, there was $x^{2}(8)=76.586, p=.000$ for online classes per day; $\mathrm{x}^{2}(16)=75.984, \mathrm{p}=.000$ for time duration of online classes per day; $x^{2}(16)=54.488, p=.000$ for monthly data for online classes; $x^{2}(16)=22.057, p=.141$ for monthly expenditure for online classes. This entailed that there was statistically significant association between academic attainment of respondents and online classes per day, time duration of online classes per day, monthly data for online classes and strength of association between the variables was very strong; but statistically no significant association between academic attainment of respondents and monthly expenditure for online classes \& strength of association between the variables was very weak. 
Table 8: Association and significance from responses to the questions regarding online classes.

\begin{tabular}{|l|l|l|l|l|l|l|l|}
\hline Variables & $\begin{array}{l}\text { Online } \\
\text { classes } \\
\text { per day }\end{array}$ & $\begin{array}{l}\text { Symmetric } \\
\text { measures }\end{array}$ & $\begin{array}{l}\text { Time } \\
\text { duration } \\
\text { of } \\
\text { online } \\
\text { classes } \\
\text { per day }\end{array}$ & $\begin{array}{l}\text { Symmetric } \\
\text { level }\end{array}$ & $\begin{array}{l}\text { Monthly } \\
\text { Data for } \\
\text { online } \\
\text { classes }\end{array}$ & $\begin{array}{l}\text { Symmetric } \\
\text { level }\end{array}$ & $\begin{array}{l}\text { Monthly } \\
\text { Expenditure } \\
\text { for online } \\
\text { classes }\end{array}$ \\
\cline { 2 - 8 } & $\begin{array}{l}\mathbf{X}^{2} \text { (p- } \\
\text { value) }\end{array}$ & $\begin{array}{l}\text { Phi \& } \\
\text { Cramer's V; } \\
\text { (Approximate } \\
\text { significance) }\end{array}$ & $\begin{array}{l}\mathbf{X}^{2} \text { (p- } \\
\text { value) }\end{array}$ & $\begin{array}{l}\text { Phi \& } \\
\text { Cramer's V; } \\
\text { (Approximate } \\
\text { significance) }\end{array}$ & $\begin{array}{l}\mathbf{X}^{2} \text { (p- } \\
\text { value) }\end{array}$ & $\begin{array}{l}\text { Phi \& } \\
\text { Cramer's V; } \\
\text { (Approximate } \\
\text { significance) }\end{array}$ & $\begin{array}{l}\mathrm{X}^{2} \text { (p- } \\
\text { value) }\end{array}$ \\
\hline $\begin{array}{l}\text { Academic } \\
\text { attainment of } \\
\text { respondents }\end{array}$ & $\begin{array}{l}\mathrm{X}^{2}(8) \\
=76.586, \\
\mathrm{P}=.000\end{array}$ & $\begin{array}{l}.331 \& .234 ; \\
(.000)\end{array}$ & $\begin{array}{l}\mathrm{X}^{2}(16)= \\
75.984, \\
\mathrm{P}=.000\end{array}$ & $\begin{array}{l}.33 \& .165 ; \\
(.000)\end{array}$ & $\begin{array}{l}\mathrm{X}^{2}(16) \\
=54.488 \\
\text { Cramer's V; } \\
\text { (Approximate } \\
\text { significance) }\end{array}$ \\
\hline
\end{tabular}

\section{DISCUSSION:}

This study investigated the perceptions of respondents regarding online classes and their difference with respect to their sociodemographic factors, the device used for online classes, and types of networks used in accessing online education etc. The study had conducted among the students of class 8 to post graduate throughout every region of Bangladesh.

In developing countries like Bangladesh, the online learning system is a very unfamiliar and newer approach [27]. As we know, the Bangladeshi educational system follows the traditional face-to-face learning method [28]. However, all educational activities are operating online during this COVID-19 pandemic [29]. The availability and technological aspects of mobile phones helped online learning to be successful because majority of the students opined to use their mobile phones in this context (Table-4). The results of this study are in agreement with a study conducted in Saudi Arabia which supported the impact of using social media applications in learning and recommended activation of these applications in English language learning [30].

According to this study's findings, most students stated that online classes are not appropriate for giving you theoretical and practical experiences and they couldn't achieve expected results through online classes that could be gathered in traditional classes (Table-5). It should be noted that there is no alternative way of online classes to conduct the e-learning classroom in this pandemic situation. Neverthless, as a developing country, Bangladesh faces some obstacles while conducting online classes [13]. Still, online classes are very fruitful for students in a pandemic situation [31]. Instead of some drawbacks in online learning, our study's findings sketched that almost half of the respondents stated that the opportunity to participate in online classes is enjoyable due to suitability of home for classes and rapid internet facility (Table-5). This statement was found similar with previous studies conducted among students of public universities [31].

The research finding revealed that overall perception of study respondents regarding online classes were not really satisfactory as they face difficulties in engaging themselves both in online classes and examinations (Table-6). However, these findings had supported by some previous studies conducted in India [32] and Nepal [33]. Another findings of the study revealed that, academic level of study respondents was found statistically significant in relation to online classes per day, time duration of online classes per day, monthly data for online classes but not with monthly Expenditure for online classes (Table-12).

\section{LIMITATIONS:}

The study was performed in a single developing country (Bangladesh) with specific settings that includes psycho social conditions of the respondents during this pandemic, the respondent's financial positions, the internet facility with cost etc. Therefore, the findings of the study may not be generalized to other developing countries, and they must be verified by conducting further studies in different geographic locations and centers to achieve an overview of the appropriateness of the online learning platform as a mode of teaching which could help determine whether online learning can replace traditional classroom lectures. Considering difficulties in accessing e-learning platform, the study did not explain how to resolve the problems and how students of all classes can cope.

\section{CONCLUSIONS:}

The COVID-19 pandemic situation is more threatening and has lasted more than the previous epidemic situations. In this circumstance, online teaching by all educational institutions has been started after the declaration of closure of educational institutions by the government of Bangladesh. Besides having fewer difficulties, the online learning has created a new means of communication between teachers and students. Based on the study results, E-learning contributes to generate mental pressure or familial pressure, add extra expense on monthly expenditure with several technical \& financial resources constraints. It is imperative to highlight many of the recommendations that could possibly have positive impact on the possibility of implementing e-learning. It is needed to introduce better internet service facility to students and teaching staff members with enough computer devices, develop dedicated classrooms with all types of educational equipment and tools, conduct regular online training and seminars by every educational institution which will be facilitated and supported by the government of Bangladesh.

\section{REFERENCES:}

1. Dubey S, Biswas P, Ghosh R, Chatterjee S, Dubey MJ, Chatterjee S, et al. Psychosocial impact of COVID-19. Diabetes Metab Syndr. 2020;14(5):779-88. https://doi.org/10.1016/j.dsx.2020.05.035

2. Habas K, Nganwuchu C, Shahzad F, Gopalan R, Haque M, Rahman S, et al. Resolution of coronavirus disease 2019 (COVID-19). Expert Rev Anti Infect Ther. 2020;18(12):1201-11. https://doi.org/10.1080/14787210.2020.1797487 
3. Pramana C, Susanti R, Violinda Q, Yoteni F, Rusdiana E, Prihanto YJN, et al. Virtual learning during the COVID-19 pandemic, A disruptive technology in higher education in Indonesia. SSRN Electron J [Internet]. 2021; Available from: http://dx.doi.org/10.2139/ssrn.3777691 https://doi.org/10.2139/ssrn.3777691

4. Koyama T, Weeraratne D, Snowdon JL, Parida L. Emergence of drift variants that may affect COVID-19 vaccine development and antibody treatment. Pathogens. 2020;9(5):324 https://doi.org/10.3390/pathogens 9050324

5. Wang L, Wang Y, Ye D, Liu Q. Review of the 2019 novel coronavirus (SARS-CoV-2) based on current evidence. Int J Antimicrob Agents. 2020;55(6):105948. https://doi.org/10.1016/j.ijantimicag.2020.105948

6. Zu ZY, Jiang MD, Xu PP, Chen W, Ni QQ, Lu GM, et al. Coronavirus disease 2019 (COVID-19): A perspective from China. Radiology. 2020;296(2):E15-25. https://doi.org/10.1148/radiol.2020200490

7. Rodriguez-Morales AJ, Public Health and Infection Research Group, Faculty of Health Sciences, Universidad Tecnologica de Pereira, Pereira, Colombia, Bonilla-Aldana DK, Tiwari R, Sah R, Rabaan AA, et al. COVID-19, an emerging Coronavirus infection: Current scenario and recent developments - an overview. J Pure Appl Microbiol. 2020;14(1):05-12. https://doi.org/10.22207/JPAM.14.1.02

8. Inicio. Repositorio.cepal.org. (2021). Retrieved 28 July 2021, from https://repositorio.cepal.org.

9. Bao W. COVID -19 and online teaching in higher education: A case study of Peking University. Human Behav and Emerg Tech. 2020;2(2):113-5. https://doi.org/10.1002/hbe2.191

10. Mulyanti B, Purnama W, Pawinanto RE. Distance learning in vocational high schools during the COVID-19 pandemic in West Java province, Indonesia. Indones J Sci Technol. 2020;5(2):27182. https://doi.org/10.17509/ijost.v5i2.24640

11. Almahasees Z, Mohsen K, Amin MO. Faculty's and students' perceptions of online learning during COVID-19. Front Educ [Internet]. 2021;6. Available from: http://dx.doi.org/10.3389/feduc.2021.638470 https://doi.org/10.3389/feduc.2021.638470

12. Rahman MHA, Uddin MS, Dey A. Investigating the mediating role of online learning motivation in the COVID-19 pandemic situation in Bangladesh. J Comput Assist Learn [Internet]. 2021;(jcal.12535). Available from: http://dx.doi.org/10.1111/ical.12535 https://doi.org/10.1111/jcal.12535

13. Al-Amin M, Zubayer AA, Deb B, Hasan M. Status of tertiary level online class in Bangladesh: students' response on preparedness, participation and classroom activities. Heliyon. 2021;7(1):e05943. https://doi.org/10.1016/j.heliyon.2021.e05943

14. Bangladesh [Internet]. Globalpartnership.org. [cited 2021 Aug 15]. Available from: https://www.globalpartnership.org/where-wework/bangladesh

15. Coronavirus outbreak, schooling and learning: Study on secondary school students in Bangladesh [Internet]. Povertyaction.org. 2020 [cited 2021 Aug 15]. Available from: https://www.poverty-action.org/recovr-study/coronavirusoutbreak-schooling-and-learning-study-secondary-schoolstudents-bangladesh

16. Khan MM, Rahman SMT, Islam STA. Online Education System in Bangladesh during COVID-19 Pandemic. Creat Educ. 2021;12(02):441-52. https://doi.org/10.4236/ce.2021.122031

17. Gaber DA, Shehata MH, Amin HAA. Online team-based learning sessions as interactive methodologies during the pandemic. Med Educ. 2020;54(7):666-7 https://doi.org/10.1111/medu.14198
18. Saha A, Dutta A, Sifat RI. The mental impact of digital divide due to COVID-19 pandemic induced emergency online learning at undergraduate level: Evidence from undergraduate students from Dhaka City. J Affect Disord. 2021;294:170-9. https://doi.org/10.1016/j.jad.2021.07.045

19. Phutela N, Dwivedi S. A qualitative study of students' perspective on e-learning adoption in India. J appl res high educ. 2020;12(4):545-59. https://doi.org/10.1108/JARHE-02-20190041

20. Mamun MA, Chandrima RM, Griffiths MD. Mother and son suicide pact due to COVID-19-related online learning issues in Bangladesh: An unusual case report. Int J Ment Health Addict. 2020;1-4. https://doi.org/10.1007/s11469-020-00362-5

21. Singh V, Thurman A. How many ways can we define online learning? A systematic literature review of definitions of online learning (1988-2018). Am J Distance Educ. 2019;33(4):289-306. https://doi.org/10.1080/08923647.2019.1663082

22. Mukhtar K, Javed K, Arooj M, Sethi A. Advantages, Limitations and Recommendations for online learning during COVID-19 pandemic era. Pak J Med Sci Q. 2020;36(COVID19-S4):S27-31. https://doi.org/10.12669/pjms.36.COVID19-S4.2785

23. Dumford AD, Miller AL. Online learning in higher education exploring advantages and disadvantages for engagement. J Comput High Educ. 2018;30(3):452-65. https://doi.org/10.1007/s12528-018-9179-z

24. Richardson JTE, Morgan A, Woodley A. High Educ. 1999;37(1):23-55. https://doi.org/10.1023/A:1003445000716

25. Ali W. Online and remote learning in higher education institutes: A necessity in light of COVID-19 pandemic. High Educ Stud. 2020;10(3):16. https://doi.org/10.5539/hes.v10n3p16

26. Shammi M, Bodrud-Doza M, Islam ARMT, Rahman MM. Strategic assessment of COVID-19 pandemic in Bangladesh: comparative lockdown scenario analysis, public perception, and management for sustainability. Environ Dev Sustain. 2020;23(4):1-44 https://doi.org/10.1007/s10668-020-00867-y

27. Gopal R, Singh V, Aggarwal A. Impact of online classes on the satisfaction and performance of students during the pandemic period of COVID 19. Educ Inf Technol. 2021;1-25. https://doi.org/10.1007/s10639-021-10523-1

28. Uzzaman MN, Jackson T, Uddin A, Rowa-Dewar N, Chisti MJ, Habib GMM, et al. Continuing professional education for general practitioners on chronic obstructive pulmonary disease: feasibility of a blended learning approach in Bangladesh. BMC Fam Pract. 2020;21(1):203. https://doi.org/10.1186/s12875020-01270-2

29. The COVID-19 pandemic has changed education forever. This is how [Internet]. Weforum.org. [cited 2021 Oct 11]. Available from:

https://www.weforum.org/agenda/2020/04/coronaviruseducation-global-covid19-online-digital-learning/

30. Kaid Mohammed Ali J, Rashad Ali Bin-Hady W. A study of EFL students' attitudes, motivation and anxiety towards WhatsApp as a language learning tool. Arab World Engl J. 2019;(5):289-98. https://doi.org/10.24093/awej/call5.19

31. Dhawan S. Online learning: A panacea in the time of COVID-19 crisis. J Educ Technol Syst. 2020;49(1):5-22. https://doi.org/10.1177/0047239520934018

32. Kapasia N, Paul P, Roy A, Saha J, Zaveri A, Mallick R, et al. Impact of lockdown on learning status of undergraduate and postgraduate students during COVID-19 pandemic in West Bengal, India. Child Youth Serv Rev. 2020;116(105194):105194. https://doi.org/10.1016/j.childyouth.2020.105194

33. Subedi S, Nayaju S, Subedi S, Shah SK, Shah JM. (2020). Impact of E-Learning during COVID-19 Pandemic Among Nursing Students and Teachers of Nepal. Int. J. Sci. Healthc. Res. 2020; 5 (3): 68-76. 